\title{
A DISCUSSION OF THE VALUES OF HISTORY
}

\author{
David M. Laushey \\ Georgia State University
}

Teaching historians probably do not devote enough time in their classes to a discussion of the values of the study of history. Fifty years ago when history occupied a more assured position in the liberal arts curriculum, an apologia for history would have been unthinkable. Today, however, when there is a growing emphasis on courses with more direct vocational application, historians should devote some conscious effort, especially in freshman classes, to an explicit defense of the values of their discipline. Teachers will teach better and students will learn better if both have some common conceptions of the values to be derived from their efforts.

I have complied a list of ten suggested values of the study of history for use in my survey courses. The list is duplicated and distributed to students to serve as the basis for discussion during one class at the beginning of each semester. It is used in conjunction with the first two chapters of Carl G. Gustavson's excellent book, A Preface to History, from which some of my ideas have been adopted.'

No claim for originality is made for any of the items in the list. The chief value of the list is that it brings together in simplified form a number of different ideas and suggestions from a variety of sources. It serves as a stimulus to thought and discussion. It is a tentative starting point, not a definitive, comprehensive final statement. It is offered here in the belief that other teachers may find some value in it and may wish to use this or a modified list, properly edited and amended to suit individual interests and opinions.

\section{Some Suggested Values of the Study of History}

1. Appreciation of Change. History is first and foremost the study of change. Without change there would be no history and no historians. In contrast to many other disciplines that investigate relatively static subjects, that can experiment, that can reproduce exact conditions and expect exact results, historians must deal with a constantly and inevitably changing set of conditions. Thus historians describe their subject in such terms as emergence, growth, evolution, development, subsidence, decline, decay. They seek to trace and explain the patterns, processes, and, above a 11, the causes of change. No other discipline concerns itself so exclusively with this phenomenon. Other disciplines may answer the question "where are we now," but the historian is best able to answer the question "how did we get here," or rather, "what were the patterns, processes and causes of change that brought us to this present condition."

2. Appreciation of Historiography. A careful study of history demonstrates that not onty is the human condition subject to constant and inevitable change, but man's perception and interpretation of his own history is also constantly changing. The study of these changing interpretations is known as historiography, a word that is perhaps most simply defined as "the history of the writing of history." An appreciation of historiography should lead one to a healthy skepticism of absolutist, dogmatic, determinist theories of history. It should al so lead one to examine with great care the glib historical generalities that political leaders and other would-be molders of public opinion constantiy invoke in order to buttress their argument. (A similar idea with more general application is expressed below under the heading of "Skepticism.") 
3. Vicarious Experience. History provides the individual with a vicarious extension in time and space of his own limited personal experience. While a single individual may enjoy a brief 60 or 70 years of direct personal experience in a lifetime, history opens up the benefits of 5,000 years of recorded human experience. If it is true that we do 1 earn from experience, then it seems reasonable to conclude that the more experience we have, both direct and vicarious, then the more we should learn. On this point, however, several words of caution: The precise "lessons" of history are never as clear-cut or as easily understood as some would have us believe. What may seem like a clear-cut lesson today may be regarded as an erroneous interpretation tomorrow.

4. Perspective. History provides perspective by permitting one to observe the relationship of one's own 1 ife and surroundings to that of previous times and places. Knowing and appreciating history is like being on a high hilltop from which one can scan the entire surrounding countryside and can discern one's position and relationship with respect to everything else.

5. Historical Insight. Although history does not enable one to predict the future, by careful 1 y plotting the trends of the past, one can make intelligent estimates of the probable broad trends of the future. Phrased somewhat more generally, the study of history provides one with what Arthur Meier Schlesinger, Ur. has called "historical insight," which he defined as "a sense of what is possible and probable in human affairs, derived from a feeling for the continuities and discontinuities of existence."

6. Pluralism. History provides an overview of the diversity and variety of human attempts to formulate solutions to the perennial questions of human existence. Especially, history demonstrates that the solutions developed by a particular people at a particular time are conditioned by their own unique historical experience and hence may not be appropriate for any other people at any other time or place. From this one should derive a profound humility about one's own ideas and institutions, avoiding both ethnocentrism and presentist chauvinism. This same idea has been expressed in somewhat different terms by W.T.K. Nugent:

A virtue of historical study is that it releases you from the prison of your own time. It permits you to see that 1 ife can be, and indeed was, different from what it is for us at present, and shows you a society (perhaps your own) at a different point in time, with different problems, different social structures, and different alternatives for meeting what was then the future.

One who has developed an appreciation for this great variety of human experience would likely be led to a pluralist social view, that is, the notion that there is no one perfect idea system or perfect way of 1 ife but rather a great range of workable possibilities. The pluralist is thus tolerant of, appreciative of, and prepared to co-exist with peoples who think and live differentiy.

7. Skepticism. A careful study of history provides a healthy skepticism of those who seek to influence public opinion in favor of this or that simplistic or erroneous ideology or plan of action and convinces one of the necessity of subjecting a 11 ideas and systems of thought to cautious testing and analysis. It thus protects one from naivete, from the 
uncritical acceptance of flashy panaceas and fashionable fads. Four general examples are suggested here to illustrate this point:

A. Elusiveness of Truth. By demonstrating that there is virtually nothing that has been believed always, everywhere, and by everyone, history promotes a skeptical attitude to the dogmatists who claim to possess absolute truth.

B. Complexity of Life. By demonstrating that most problems in human society are usualTy complex, history promotes a skeptical attitude to the demagogues who claim to have simple, pat answers to all problems.

C. Inevitability of Change. By demonstrating the inevitability of change, history promotes a skeptical attitude to hard-headed conservatives who oppose all change and to naive reactionaries who seek to return to some golden age of the past.

D. Slowness of Change. By demonstrating that all great changes take place very slowly, history promotes a skeptical atti tude to emptyheaded liberals who advocate change for its own sake and to naive radicals who seek to reconstruct society overnight into some golden age of the future.

8. Empiricism. History is the ultimate empirical discipline in the social sciences and humanities. That is, it relies almost exclusively on inductive rather than deductive method. Therefore, it is the essential complement to theorists and system-builders. It provides the testing grounds for hypotheses in other social sciences in cases where direct experimentation is impossible. History asks the one simple question: What in fact did happen? While the question is simple, the answer is generally complex.

9. Humanism. Because history retains strong roots in the humanities while alsoclaiming membership in the social sciences, it provides the essential complement to those disciplines that focus primarily on social groups. The study of group behavior is important, of course, but it sometimes tends to depersonalize the individual, to treat the individual as a case study or as an entry in a statistical table. History is like a social science in that it is also concerned with groups, but it nevertheless retains its humanistic emphasis on the significance of the unique individual human being.

10. Responsible Citizenship. History has been used by virtually every government of modern times to promote patriotism in its citizens. Unfortunately, patriotism has frequently been construed to mean an unthinking loyalty to the nation, an uncritical acceptance of a nation's past glories, a blind adulation of a nation's folk heroes. Rather than patriotism, an objective study of history should promote what might better be termed responsible citizenship. This implies a full understanding of the origins, development, and present-day workings of social, economic, and governmental institutions, a critical evaluation and judgment of a nation's past and present policies, and a conscientious concern for the future welfare of the nation manifested by a willingness and a capacity to participate actively and effectively in the democratic processes. It implies also the possession of those characteristics and qualities listed above. A responsible citizen is one who cannot be "taken in" by the demagogues or the ideologues, who has a health skepticism of simplistic 
solutions and pat answers, who is flexible of mind, cosmopolitan and sophisticated in experience, demanding and exacting in search of truth, and humble in spirit.

\section{NOTES}

${ }^{1}$ Carl G. Gustavson, A Preface to History (New York, 1955).

${ }^{2}$ Arthur Meier Schlesinger, Jr., The Bitter Heritage (Boston, 1967), 84.

3 W. T. K. Nugent, Creative History (2nd ed.; Philadelphia, 1973), 21. 